\title{
Further Observations on the Fossil Flower, Cretovarium.
}

\author{
BY
}

\author{
MARIE C. STOPES, D.Sc., PH.D., F.L.S. \\ Lecturer in Fossil Botany, Manchester University.
}

With Plates LVI and LVII.

$O^{B}$

BFECT of the paper: To record the discovery of, and shortly to describe, ovules in an ovary of Cretovarium japonicum, Stopes and Fujii ; and to illustrate the structure of the ovary wall.

Although the original description ${ }^{1}$ is based on seven specimens of the ovary of Cretovarium, one of them showing the placentae, none of these contained any ovules.

I have recently found an ovary containing several ovules, and now describe it in order to supplement the earlier account of the new fossilwhich has for the moment added to its merely academic a somewhat adventitious interest, owing to the fact that it is the only known structural petrifaction of a true angiospermic flower.

The ovary containing the ovules is shown in Photograph I, Pl. LVI, in transverse section. It is from a region apparently slightly above the equator of the carpels, where it is free from the perianth. (It will be remembered that the perianth is adherent to the lower region of the carpels.)

In the specimen, the cavities of the loculi are completely filled with black granules of matrix, in which the ovules stand out as shadowy, lighter patches in the photograph. The diagram in Pl. LVII, Fig. I, gives an outline of the same, and shows the position and extent of the ovules, of which there are so many as five in the complete loculus.

The petrifaction of the ovules is, unfortunately, far from perfect, but they closely resemble in appearance ovules in preparations of modern plants which have not been well fixed. The enlarged drawing in Fig. 3, P1. LVII, shows the details of the ovules numbered 2, 3, and 4 in Fig. I. From this it will be seen that but little definite cell structure is retained,

1 Stopes and Fujii, Studies on the Structure and Affinities of Cretaceous Plants. Phil. Trans. Royal Soc. B., vol. cc, I910.

[Annals of Botany, Vo1. XXIV.No. XCVI. October, 1910.] 
except what, from comparison with recent ovules similarly imperfect, must be taken as the outer integument. This is also seen in Fig. 2, which is an enlargement of ovule No. 6, and shows the cells of the integument comparatively well preserved, but the inner tissue broken down to form a granular, contracted mass. Ovule No. I is seen somewhat enlarged in Photograph 2, Pl. LVI.

All the ovules are cut obliquely and tangentially, and none are attached to their placentae. Ovule No. 2, however, suggests that they were anatropous.

As there were five ovules in the one transverse section, it is probable that there would have been about twenty or so in each loculus, since the ovary is not more than $3 \mathrm{~mm}$. in vertical height.

The features shown, or suggested, by these ovules appear entirely similar to those of normal modern anatropous ovules, and are in agreement with the original allocation of the plant, presumably to the Liliaceae.

I take this opportunity further to illustrate the details of the ovary wall, which was shown very imperfectly in the three photographs illustrating the original description; partly owing to their comparatively small scale, and partly to the fact that the preservation of the outer coat of the ovary in those specimens was far from perfect. Round the inner zone of thickwalled fibres there was indeed only a much-decomposed remnant of tissue, and it was then suggested that it was the remains of a soft-celled outer envelope surrounding the fibrous wall, although it was not possible to establish this at the time. In the present specimen this supposition is substantiated, for the soft outer tissues are well preserved, as is seen in the Photographs I and 2, and Drawing 3, Pl. LVII, at ow.

The cells of this soft zone vary somewhat in size, but are roundish and undifferentiated; a number of them have clear yellowish content, which suggests that they contained mucilage or tannin while alive.

It seems not unlikely that this ovule-bearing ovary was slightly younger at the time of its petrifaction than those previously described; and that in the others it was not merely bad petrifaction which left the outer wall so disintegrated, but the natural decomposition of this layer in the ripe carpel. 


\section{DESCRIPTION OF PLATES LVI AND LVII.}

Illustrating Dr. Marie C. Stopes's paper on the Fossil Flower, Cretovarium.

\section{PLATE LVI.}

Phot. I. Transverse section of the ovary lying in the granular matrix. It shows the three loculi, the double-layered wall, and the ovules in the loculus, which appears black owing to the granules of the matrix. Cf. Fig. I, Pl. LVII. $\times 44$ diameters.

Phot. 2. Enlargement of part of the upper loculus, showing the cells of the ovary wall (ow) and the inner fibrous layer $(f)$. At $a$ is the ovule No. I in Fig. I, Pl. LVII; $b$, the ovule No. 2 in Figs. 1 and 3 , Pl. LVII; $c$, the small cells of the axis of the carpels.

\section{PLATE LVII.}

Fig. I. Diagram showing the outline of the ovary and the ovules contained, numbered I, 2, \&c.

Fig. 2. Drawing of details of ovule No. 6.

Fig. 3. Drawing of details of ovary wall (ow, soft, outer cells; $f$, fibres) and of ovules Nos. 2, 3 , and 4 . 


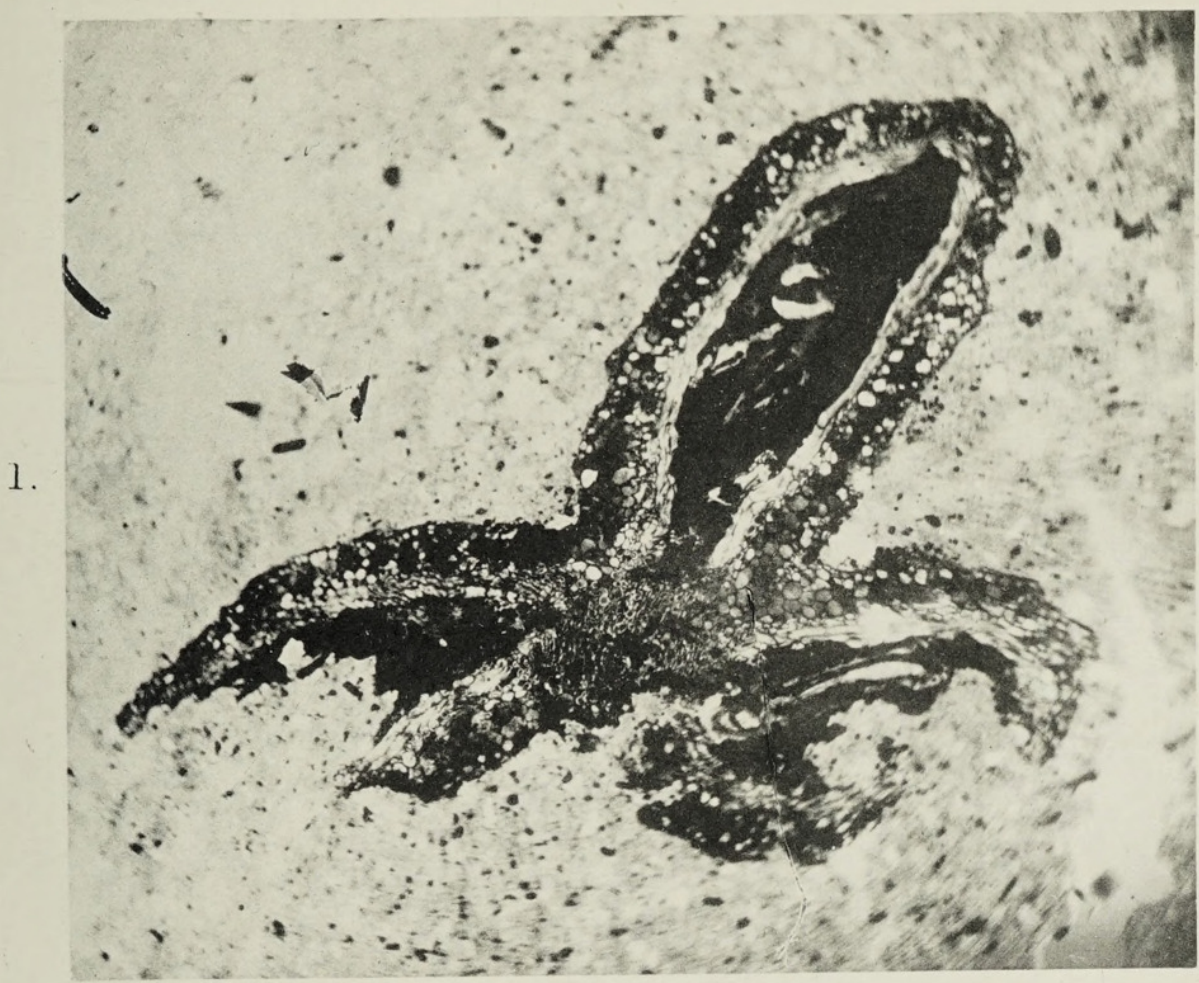

2.

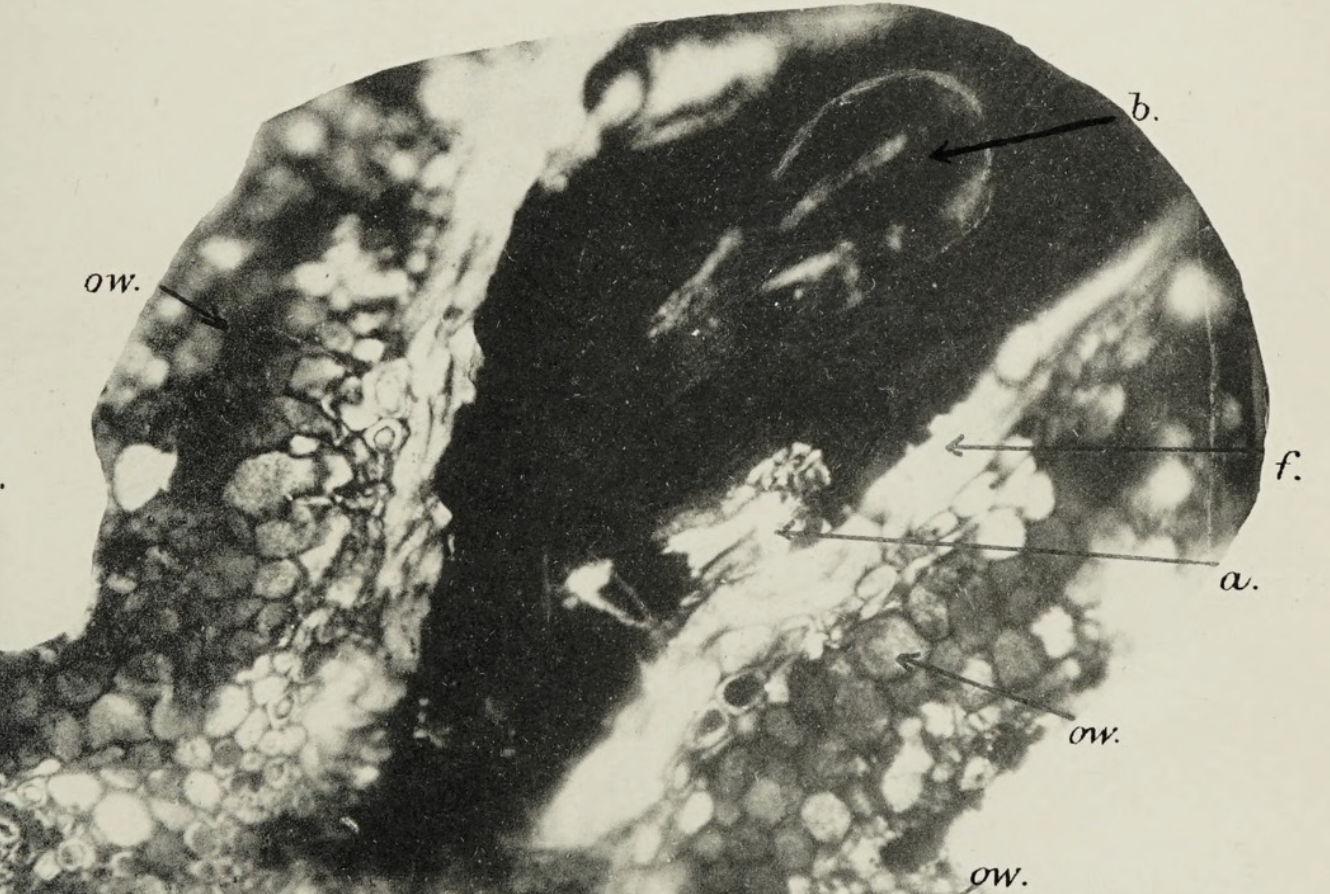

(a)

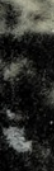

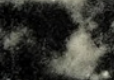

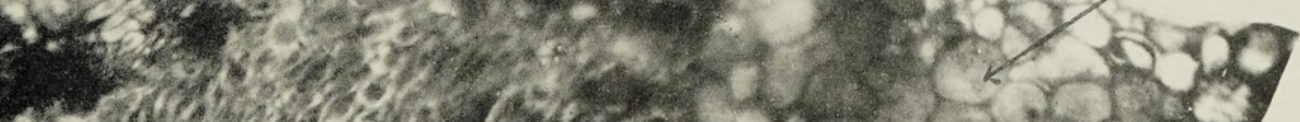

-

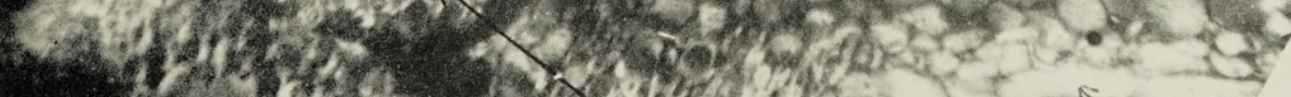

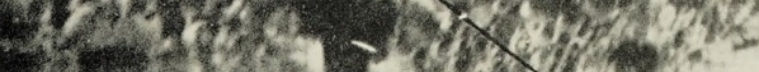

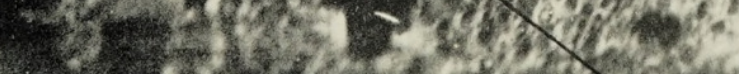

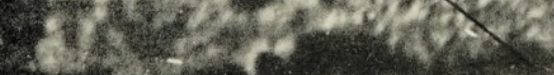

c.

STOPES. 

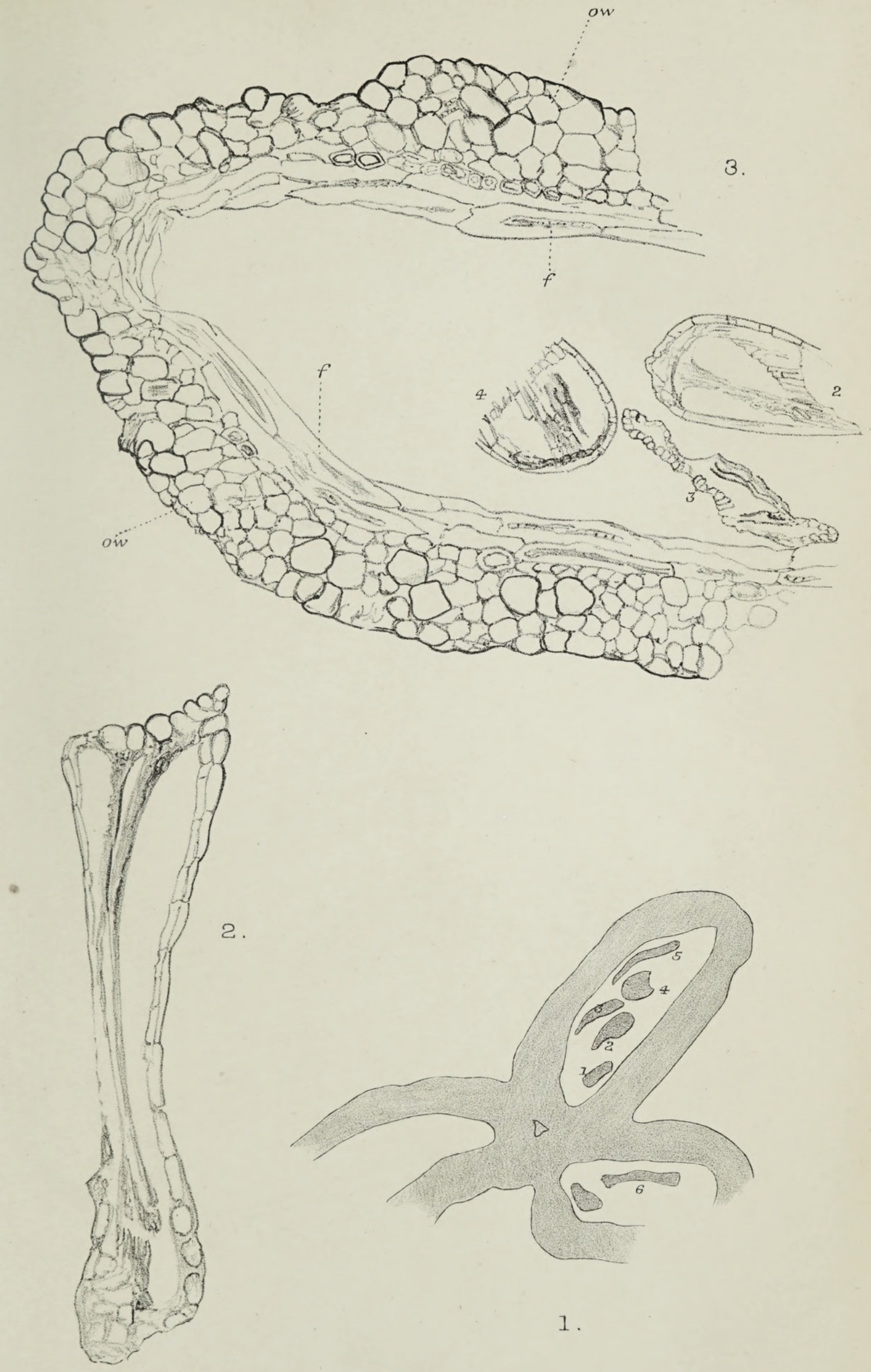

1. 


\section{$2 \mathrm{BHL}$ Biodiversity Heritage Library}

Stopes, Marie Carmichael. 1910. "Further observations on the fossil flower, Cretovarium." Annals of botany 24, 679-681.

https://doi.org/10.1093/oxfordjournals.aob.a089298.

View This Item Online: https://www.biodiversitylibrary.org/item/262605

DOI: https://doi.org/10.1093/oxfordjournals.aob.a089298

Permalink: https://www.biodiversitylibrary.org/partpdf/319806

\section{Holding Institution}

New York Botanical Garden, LuEsther T. Mertz Library

\section{Sponsored by}

BHL-SIL-FEDLINK

\section{Copyright \& Reuse}

Copyright Status: Public domain. The BHL considers that this work is no longer under copyright protection.

This document was created from content at the Biodiversity Heritage Library, the world's largest open access digital library for biodiversity literature and archives. Visit BHL at https://www.biodiversitylibrary.org. 